\title{
Pheromone Trap Position: A Key Factor Considered During Mass Trapping Programme of Opisina arenosella Walker
}

\author{
Chandrashekharaiah Muniyapp ${ }^{1 *}$, KRM Bhanu' ${ }^{2}$ AK Chakravarthy' ${ }^{1}$, MS Prabhakar ${ }^{2}$ and B Mallik \\ ${ }^{1}$ Department of Entomology, University of Agricultural Sciences, India \\ ${ }^{2}$ Pest Control India Pvt Ltd (Bio-Control Research Laboratories), India
}

Submission: February 24, 2018; Published: April 04, 2018

"Corresponding author: Chandrashekharaiah Muniyapp, Department of Entomology, University of Agricultural Sciences, GKVK, Bangalore, Karnataka, India, Email: chandu.raiah@gmail.com

\begin{abstract}
The black-headed caterpillar, Opisina arenosella Walker (Lepidoptera: Oecophoridae), is an important defoliating pest on coconut in the Oriental. The 0 . arenosella has often reported for its infestation in epizootic proportions on coconut palms since 1920. Parasitoids have frequently been released by the Agriculture Department for its suppression and stem and root feeding of synthetic insecticides has also commonly been practised. But, trapping of male moths using pheromone traps is currently gaining importance for the management of O. arenosella. Standardisation of trapping techniques and pheromone trap placement is a very crucial factor for successful pest management. Current studies revealed that the differences in mean catches of 0 . arenosella was significantly differed in the traps placed at the centre, border and outside the coconut orchard. The 0 . arenosella male moths were more attractive to the trap placed at inside the palm field. Further, moth catches in the traps placed within the palm canopy was significantly more than the traps placed outside the coconut field and traps placed at the end of the fronds than those placed at the bottom of the fronds. Our results suggest suitable trap placement significantly attract more 0 . arenosella moths on coconut ecosystem.
\end{abstract}

Keywords: Black-headed caterpillar; Coconut; Pest management; Pheromone; Trap

\section{Introduction}

The black-headed caterpillar, Opisina arenosella Walker (Lepidoptera: Oecophoridae), is a defoliating coconut (Cocos nucifera L.) pest with spatially segregated population and discrete flight period [1]. Early stage larvae gregariously and later instars solitarily feed and confine under-surface of leaflets constructing galleries of silk, frass and chewed matters. In the severely infested orchards give the burnt-up appearance and reduced nut production [2]. Its menace has been highlighted frequently in India, Sri Lanka, Myanmar and Bangladesh [3]. The 0 . arenosella has often reached epizootic proportions on coconut palms since 1920. Parasitoids like Goniozus nephantidis Muesebeck (Hymenoptera: Bethylidae) and Bracon brevicornis Wesmael (Hymenoptera: Braconidae) have frequently been released by the Agriculture Department for the suppression of O. arenosella South India, but without the success [4]. Stem and root feeding of synthetic insecticides has also commonly been practised. But, insecticides have proved to exacerbate the pest problem, escalating the costs. To have any hope at all of success, such methods of control require the involvement of the entire Community and stringent stage-specific application of the management procedures. Mass trapping, on the other hand, can now be shown to provide an efficient means of controlling $O$. arenosella [5].

Pheromone-based trapping of male moths allows trapping sexually active male moths using species-specific pheromone, leading to a successful reduction of targeted pest population in the subsequent generations in a specified area. Lepidopteran sex pheromone is usually species-specific, requires minute quantities of pheromone compound in the lure and are environmentally friendly [6]. For successful management of pest by male trapping programme, both pheromone lure and trapping technique are crucial. Pheromone lure under field conditions should attract more number of active male moths than towards the calling female. Similarly, trapping design like trap type and density per ha were also essential for trapping more male moths 
[5]. Movement and flight activity of moths within and outside the field is also important criteria to be considered when planning for pheromone trapping technique. So that the trap catches will be maximised either by placing the traps in the zone where mating and flight activities usually occur. The position of pheromone trap placement under field condition is rarely considered in the pheromone trapping techniques.

The assessment of insect movement is an important factor determining the management tactics. A majority of insect species do not show an innate behavioural migration, rather populations expand into favourable new habitats by random spatial changes. Studies have focused largely on large-scale migration of moths and locusts at high altitudes, ignoring migration on a smaller scale. Short-range migration is certainly as important biologically as long-range dispersal and is probably more important in understanding the local population dynamics. One of the prominent behaviours of BHC, its infestation has been recorded for a long period in the same field if there is no biotic and abiotic pressure affecting it. This may be due to its poor flying capacity. If the coconut gardens are in the contiguous area, this pest slowly spreads from one field to another and finally spreads in the entire belt. By considering this behaviour of the pest present study was designed to study the effect of trap placement on moth catches.

\section{Material and Methods}

Experiments were conducted in the coconut groves near Bengaluru $\left(12.97^{\circ} \mathrm{N}, 7.56^{\circ} \mathrm{E}, 920 \mathrm{~m}\right.$ AMSL) South India. The wing-vane trap and pheromone lure containing (Z,Z,Z)-3,6,9Tricosatriene used in this study were supplied by the Bio-Control Research Laboratory (BCRL), Pest Control India, Pvt. Ltd., (PCI) Bengaluru. The following is a brief description of the procedure of individual experimental.

Study 1: Two 0 . arenosella infested coconut garden at Bidadi, one was six ha $\left(13^{\circ} 12^{\prime} 05.24^{\prime \prime}\right.$ N77 ${ }^{\circ} 17^{\prime} 50.08^{\prime \prime} \mathrm{E}, 896.112 \mathrm{~m}$ AMSL) and another was one ha $\left(12^{\circ} 45^{\prime} 38.21^{\prime \prime} \mathrm{N} 77^{\circ} 25^{\prime} 50.51^{\prime \prime} \mathrm{E}\right.$ $703.7832 \mathrm{~m} \mathrm{AMSL}$ ) were selected. A total of 18 pheromone traps installed each at centre, border and outside the fields. Traps were distributed randomly within and a border of the fields. Whereas, pheromone traps placed outside were $10 \mathrm{~m}$ away from the field, distributed throughout the periphery of the fields in all directions.

Study 2: This study was conducted in 0.37 ha coconut field at Bidadi (1245'62.13" N77²5'49.63'”, 703.7832 m AMSL). A total of 15 pheromone traps were deployed outside the coconut palm, but inside the field using bamboo sticks. Similarly, 15 traps were placed within the coconut palms in the same field. Both were placed at randomly selected palms within the field.

Study 3: The male moth catches in the pheromone trap suspended at centre and periphery of the palm canopy was studied at Bidadi $\left(13^{\circ} 12^{\prime} 05.24^{\prime \prime}\right.$ N77²17'50.08'E, 896.112m AMSL). A total of 20 pheromone traps for each treatment, placed at centre (starting point of the front) and periphery (the end/tip of the fronds) of the palm canopy in a randomly selected coconut palm.

\section{Statistics}

Weekly trap counts were pooled in each treatment and transformed $(\log (\mathrm{x}+1))$ before analysis. Moth catches were analysed using Generalized Linear Models-Univariate followed by the least significant difference (LSD; P<0.05) (SPSS 13.0 Windows). Pair-wise statistical (t-test) tool was used for comparing two means (Microsoft Excel: version 2010).

\section{Results}

Study 1: Differences in mean catches of 0 . arenosella was significantly differed in the traps placed at the centre, border and outside the coconut orchard (Location $1: \mathrm{F}=47.43$, $\mathrm{df}=2,37$, $\mathrm{P}<0.01$; Location 2: $\mathrm{F}=12.38$ 47.43, $\mathrm{df}=2,37, \mathrm{P}<0.01$ ). At location 1 , mean catch in the traps did not differ significantly between centre and border but was significantly more number of moths than outside the field (Figure 1). At location 2, however, a similar result was noticed but moth catch was not differed significantly between the traps placed at the border and outside the field. Results suggested that the 0 . arenosella male moths were more attractive to the trap placed at inside the palm field.

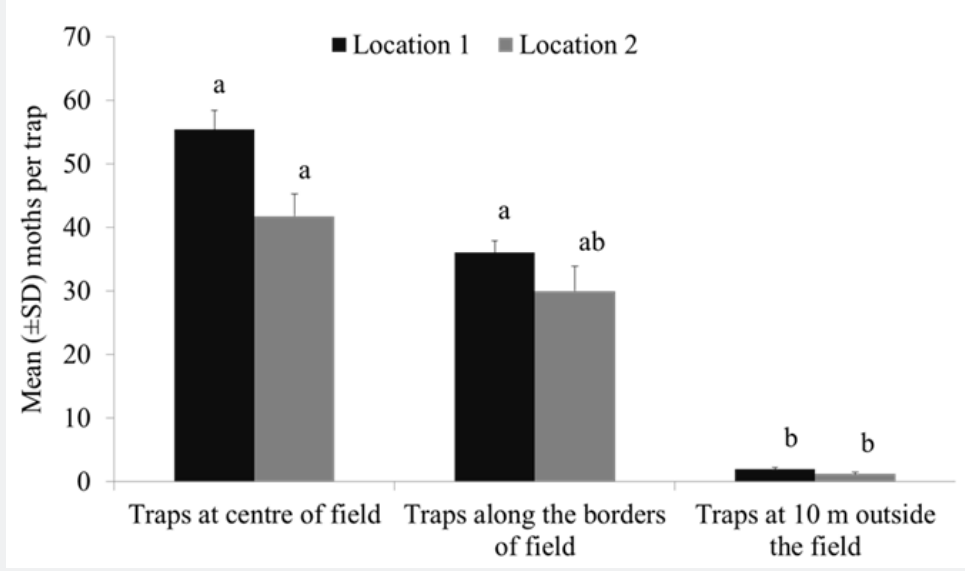

Figure 1: Male moth trapped in pheromone traps placed at centre, along the border and outside the garden. 
Study 2: Moth catches in traps placed within the palm canopy was significantly more than the traps placed outside the coconut field ( $\mathrm{t}$ value $=7.99, \mathrm{df}=2, \mathrm{p}=0.001$ ). The results indicated that the traps kept within the palm canopy trapped significantly more number of male moths than the traps kept away from the palm (Figure 2). Nearly, 62 percent of the moth catches were recorded in the pheromone traps placed within the palm canopy than the trap placed at outside the palm canopy.

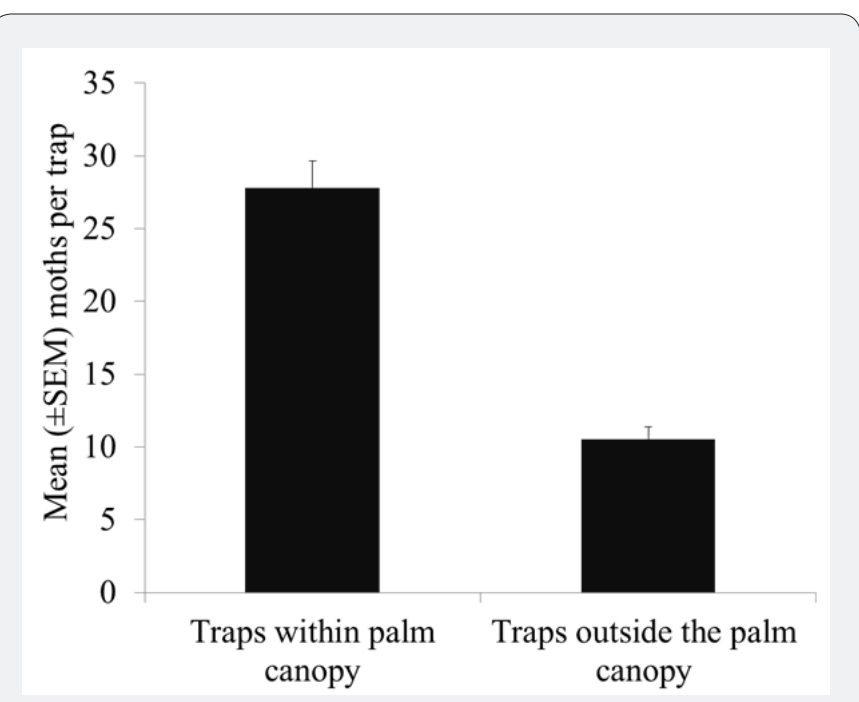

Figure 2: Mean number of moths trapped in pheromone traps placed within palm canopy and away from the canopy.

Study 3: The trap catch data revealed that significantly ( $t$ value $=11.052, \mathrm{df}=39, \mathrm{P}$ value $=0.001$ ) highest number of moths were trapped in the pheromone traps placed at the end of the fronds than those placed at the bottom of the fronds. By placing the trap at the periphery of the tree canopy 64 percent more moths are trapped than in traps placed near the centre of the canopy (Figure 3).

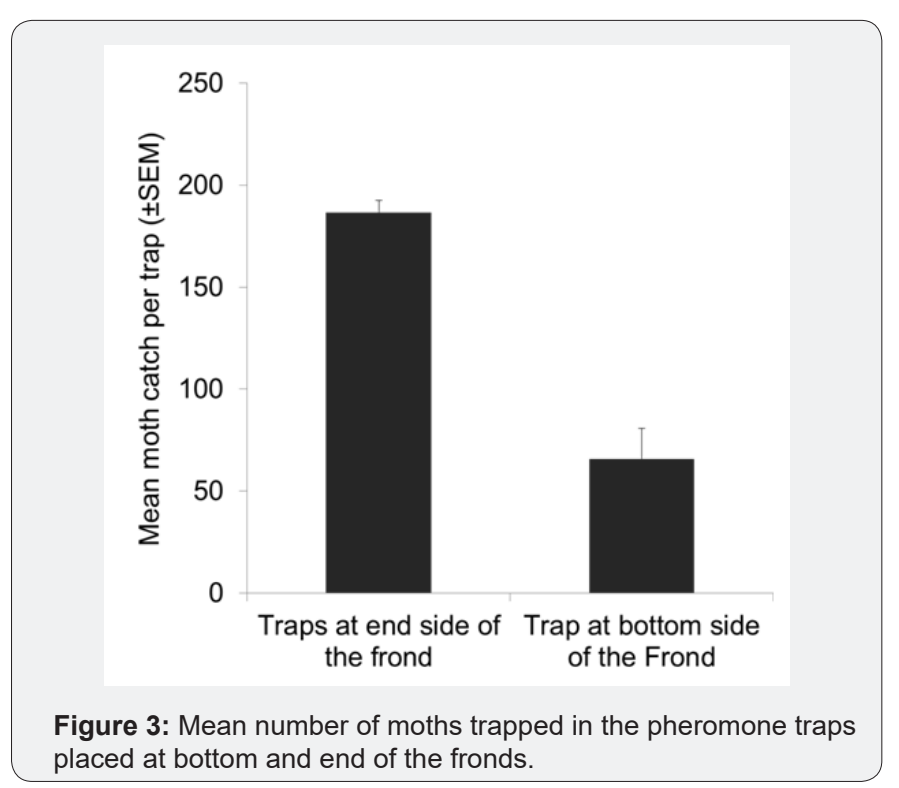

\section{Discussion}

Pheromone trapping technique not only enhances the efficiency of moth catches, but also augment the adult moths from the surrounding area [7]. Pheromone trap placement either at border or centre of the orchards depends on the pests load within the field and also their migratory behaviour. In recent years, 0 . arenosella infestation is recorded as a large contiguous patch of $1-10 \mathrm{~km} 2$. Otherwise, the infestation is always restricted to a particular block and such blocks scattered within the uninfested plantation blocks. The flight period of 0 . arenosella across the locations are differed i.e. spatially segregated populations and such populations remain in an isolated patch for a long period, without infesting nearby fields. Similarly, the o. arenosella of the particular locality have the discrete flight periods i.e. moth emergence of particular generation does not coincide with the next generation. So that, in a year nearly five flight periods were noticed in India [8]. Adults are poor flyers and usually confined within the palm, specifically the lower surface of the leaflets and rarely on the trunk of the palm and ground vegetation [9]. Further, studies on population distribution in different fronds marked from the base to top indicated the low population in lower and upper canopy than that in middle canopy. In this context, pheromone trap placement either at border/centre of the fields or uniform distribution is an essential criterion for pheromone trapping technique [9] Trap placement was an important factor when monitoring and mass trapping of the crop pests. Earlier studies focussed on sex pheromone dosage, lure type, pheromone release rate, trap type, trap color and trap density $[1,5]$. The present study was intended to assess the position of trap within or outside the coconut orchard, on or vicinity of the coconut palm and above, below and within the coconut palm canopy on moth catches.

Within the garden, moths were concentrated under the palm canopy. Traps placed at the tip of the fronds trapped more number of moths than those at the base of the fronds. It is indicating that moth activity was more at an upper third portion of the palm canopy, preferably at the periphery. The moth activity is low at outside and moderates at the border of the field. Studies on the distance from which moths can sense the pheromone lures are being planned for the next term to understand these differences. These studies clearly indicated the weak dispersal ability of male moths and also poor flying capacity from one field to other fields. One of the prominent behaviours of $O$. arenosella is to stay for a long time in the same field if no biotic and a biotic pressure affecting it. This may be due to its poor flying capacity. If the coconut gardens are in a continuous belt, this pest slowly spread from one field to other field and finally spreads to the entire belt. Several studies conducted in conventional orchards found that male moth catches were several folds higher in traps placed on the borders versus the interior of orchards $[10,11]$. The threshold level based on moth catches in the interior traps, but catches in the border traps were used for assessing immigration 
into the orchards from outside sources and to recommended border spray [10,11]. High male counts in border placed traps were typical, but whether these counts represented with-in orchards or extra orchard populations varied among sites. The threshold level of codling moth in apple orchards based on moth catches in the interior traps. But catches in the border traps were used for assessing immigration into the orchards from outside sources and recommended border spray. From these studies, it is inferred that the male moths activity were more within garden than the outside [10].

If the monitoring and elimination of BHC male moths from a field are contemplated, it is better to install traps at the periphery of the middle palm canopy. This is because moths are active at this height and coincide with the optimum or threshold flight height of the moths.

\section{References}

1. Chandrashekharaiah M (2013) Pheromone mass trapping technology for management of coconut black-headed caterpillar, Opisina arenosella walker (Lepidoptera: Oecophoridae) in Southern Karnataka (PhD dissertation). University of Agricultural Sciences, Bangalore, India.

2. Perera PACR, Hassell MP, Godfray HCJ (1989) Population dynamics of the coconut caterpillar, Opisina arenosella Walker (Lepidoptera: Xyloryctidae), in Sri Lanka. Cocos 7: 42-57.

3. Rao YR, Cherian MC, Ananthanarayanan KP (1948) Infestations of Nephantis serinopa Meyrick in South India, and their control by the biological method. Indian Journal of Entomology 10: 205-247.
4. Nagarkatti S (1973) Biological control campaign against Nephantis serinopa Meyrick in India in the light of modern concepts. Journal of Plantation Crops 1(1\&2): 28-31.

5. Muniyappa C, Bhanu KRM, Chakravarthy AK, Seetharama PM, Mangalgikar P, et al. (2017) Factors affecting catch of the black-headed caterpillar, Opisina arenosella Walker in sex pheromone-baited traps and evidence for population suppression by mass trapping, Oriental Insects.

6. El-Sayed EM, Suckling DM, Wearing CH, Byers JA (2006) Potential of mass trapping for longterm pest management and eradication of invasive species. Journal of Economic Entomology 99(5):1551-1564.

7. Hongxia Liu, Zhixiong Liu, Haixia Zheng, Meihong Yang, Jinlong Liu, et al. (2015) Effect of Trap Orientation and Interval Distance on Captures of Isoceras sibirica Alpheraky (Lepidoptera: Cossidae). Journal of Agricultural Science 7(4): 161-166.

8. Bhanu KRM, Chandrashekharaiah M, Prabhakar MS, Mallik B, Muralidharan $\mathrm{K}$, et al. (2013) Monitoring emergence pattern of coconut black-headed caterpillar, Opisina arenosella Walker (Lepidoptera: Oecophoridae). Cord 29(2): 29-36.

9. Pushpalatha NP (1991) Population ecology of coconut black headed caterpillar Opisina arenosella walker (Lepidoptera: Xylorictidaet), PhD dissertation. University of Agricultural Sciences, Bangalore, USA.

10. Madsen HF, Vakenti JM (1973) Codling moth (Lepidoptera: Olethreutidae): Codlemone $®$-baited traps and visual detection of entries to determine need of sprays. Environ Ent 2: 677-679.

11. Westigard PH., Graves KL (1976) Evaluation of pheromone baited traps in a pest management program on pears for codling moth control. Can Entomol 108: 379-382.
Your next submission with Juniper Publishers will reach you the below assets

- Quality Editorial service

- Swift Peer Review

- Reprints availability

- E-prints Service

- Manuscript Podcast for convenient understanding

- Global attainment for your research

- Manuscript accessibility in different formats

( Pdf, E-pub, Full Text, Audio)

- Unceasing customer service

Track the below URL for one-step submission https://juniperpublishers.com/online-submission.php 